\title{
WYZNACZANIE WYBRANYCH PARAMETRÓW GEOTECHNICZNYCH PREKONSOLIDOWANYCH GRUNTÓW SPOISTYCH NA PODSTAWIE SONDOWAŃ SDMT
}

\author{
Paweł Galas, Zbigniew Lechowicz ${ }^{\otimes}$ \\ Wydział Budownictwa i Inżynierii Środowiska, Szkoła Główna Gospodarstwa Wiejskiego w Warszawie
}

\begin{abstract}
STRESZCZENIE
W artykule przedstawiono wyniki badań dylatometrycznych SDMT przeprowadzonych na wybranych obiektach doświadczalnych na terenie Warszawy. Badania przeprowadzono w prekonsolidowanych gruntach spoistych. Artykuł zawiera krótką charakterystykę obiektów doświadczalnych z opisem warunków geotechnicznych i przeprowadzonych badań. Na podstawie porównania wyników badań laboratoryjnych z wynikami SDMT dokonano oceny możliwości wykorzystania nomogramu Marchettiego i Crappsa do określenia rodzaju i stanu badanych gruntów spoistych. Analiza wyników sondowań SDMT pozwoliła na opracowanie dla badanych gruntów spoistych zależności empirycznej pomiędzy stosunkiem $G_{0} / E_{D}$ i wskaźnikiem materiałowym $\left(I_{D}\right)$.
\end{abstract}

Słowa kluczowe: dylatometr sejsmiczny, grunty prekonsolidowane, sztywność gruntu, początkowy moduł ścinania

\section{WSTĘP}

Sondowanie dylatometryczne DMT zostało wprowadzone we Włoszech przez prof. Silvano Marchettiego pod koniec lat 70. XX wieku. Marchetti (1980) zaproponował zestaw zależności empirycznych pomiędzy wskaźnikami dylatometrycznymi a rodzajem gruntu, współczynnikiem parcia bocznego w spoczynku $\left(K_{0}\right)$, wskaźnikiem prekonsolidacji $(O C R)$, modułem ściśliwości $(M)$, wytrzymałością na ścinanie bez odpływu $\left(\tau_{f u}\right)$ i innymi parametrami. Uzupełnienie oprzyrządowania wykorzystywanego do wykonywania badań dylatometrycznych o dwa geofony w dylatometrze sejsmicznym SDMT rozszerzyło możliwości interpretacji badań dylatometrycznych. Zastosowanie geofonów umożliwiło wykonywanie dodatkowego pomiaru w postaci prędkości fali poprzecznej $\left(V_{s}\right)$. Mimo iż dylatometr sejsmiczny w swojej obecnej wersji wykorzystywany jest dopiero od kilkunastu lat, istnieje już obszerna literatura omawiająca zastosowanie badań SDMT do oceny parametrów geotechnicznych oraz projektowania konstrukcji geotechnicznych (Młynarek, Gogolik i Marchetti, 2006; Marchetti, 2014).

Brak rozwiązań teoretycznych umożliwiających interpretację badań dylatometrycznych powoduje, że wyprowadzanie parametrów geotechnicznych na ich podstawie wymaga zastosowania zależności korelacyjnych (Marchetti, 1980, 2014). Z tych względów zbieranie oraz przekazywanie doświadczeń o gruntach innych niż stanowiące podstawę dotychczas opracowanych zależności jest niezwykle ważne. W niniejszym artykule przedstawiono wyniki badań przeprowadzonych na obiektach doświadczalnych zlokalizowanych w Warszawie, gdzie zalegają prekonsolidowane grunty spoiste.

\footnotetext{
$\otimes_{\text {zbigniew_lechowicz@sggw.pl }}$
} 


\section{MATERIAt}

Badania terenowe wraz z towarzyszącymi badaniami laboratoryjnymi przeprowadzono na trzech obiektach doświadczalnych znajdujących się na terenie Warszawy. Pierwszy z obiektów doświadczalnych znajdował się na terenie kampusu SGGW, zlokalizowanego w południowej części Warszawy, w gminie Ursynów. Badane grunty spoiste to utwory zlodowacenia Warty i Odry o miąższości około $5 \div 6 \mathrm{~m}$, które przykrywają nasypy niebudowlane o zróżnicowanej miąższości oraz piaski gliniaste i pyły z domieszką substancji humusowych. Warstwę gruntów spoistych podścielają czwartorzędowe piaski interglacjału mazowieckiego o miąższości od 15 do $20 \mathrm{~m}$, których strop zalega na głębokości od 10 do $20 \mathrm{~m}$ poniżej powierzchni terenu. Na obiekcie Ursynów występuje jeden poziom wodonośny, swobodne zwierciadło wody gruntowej występuje w piaskach na głębokości od 10 do $14 \mathrm{~m}$ poniżej poziomu terenu (rys. 1a).

a

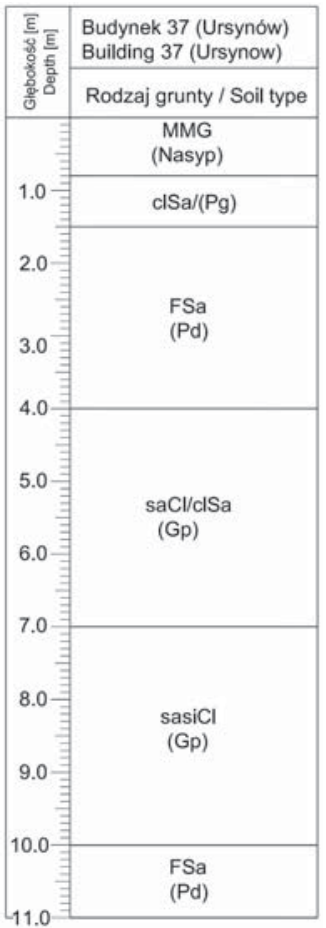

$\mathrm{b}$

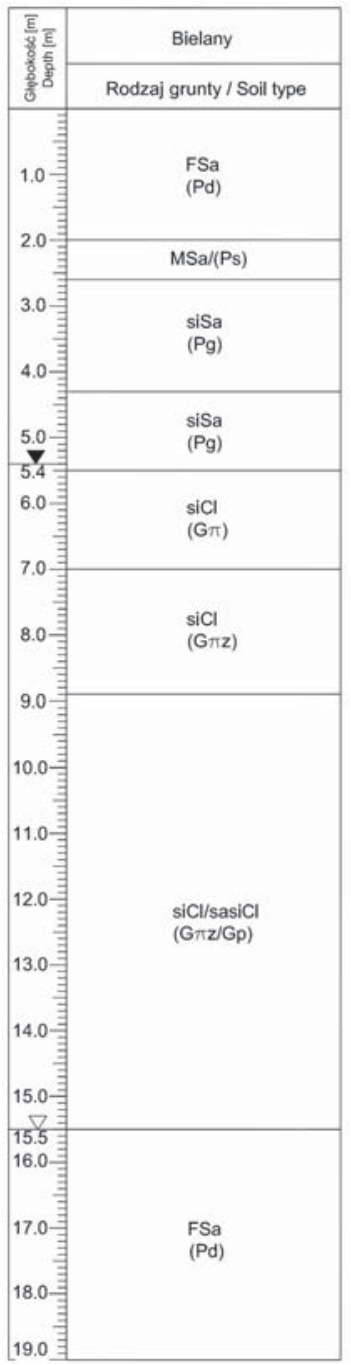

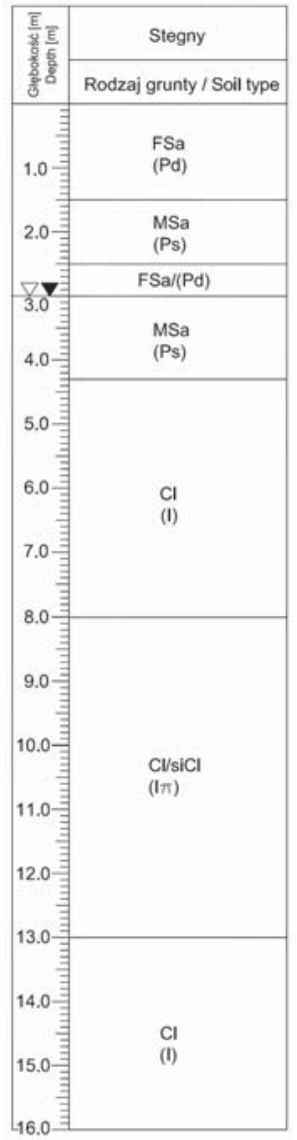

Rys. 1. Przykładowe profile dla poszczególnych obiektów doświadczalnych: a - obiekt Ursynów, b - obiekt Bielany, c - obiekt Stegny

Fig. 1. The examples of borehole logs at the test sites: $\mathrm{a}-$ Ursynów, $\mathrm{b}-$ Bielany, $\mathrm{c}-$ Stegny 
W przypadku drugiego obiektu doświadczalnego badania wykonano na terenie działki przeznaczonej do zabudowania 7-kondygnacyjnym zespołem mieszkaniowym z dwiema kondygnacjami podziemnymi „Bielany”. Teren badań zlokalizowano pomiędzy ulicami Nocznickiego i Rokokową w Warszawie. Badane grunty spoiste to utwory morenowe i zastoiskowe zlodowacenia Warty o miąższości około $10 \div 12 \mathrm{~m}$ i stropie zalegającym od 5 do $6 \mathrm{~m}$ p.p.t. (rys. 1b). Wody gruntowe charakteryzujące się swobodnym zwierciadłem stwierdzono lokalnie na głębokościach $1,8 \div 4,3 \mathrm{~m}$ p.p.t. lub w postaci sączeń w piaszczystych przewarstwieniach utworów spoistych. Główny poziom wodonośny nawiercono na głębokości $15 \div 20$ m p.p.t., ma on charakter napięty i stabilizuje się na głębokości około $5 \mathrm{~m}$ p.p.t.

Trzeci z obiektów doświadczalnych zlokalizowany został na terenie osiedla mieszkaniowego Stegny u zbiegu ulic Czarnomorskiej i Warneńskiej w Warszawie. Położony jest on w dolinie Wisły, na tarasie nadzalewowym. Badane grunty spoiste to utwory trzeciorzędowe wykształcone w postaci iłów oraz iłów pylastych. Grunty spoiste przykryte są piaskami drobnymi i średnimi z okresu zlodowacenia Wisły o miąższości 4,0 $\div 5,0 \mathrm{~m}$ (rys. 1c). Zwierciadło wody gruntowej o charakterze swobodnym występuje na głębokości około 3,0 m p.p.t.

\title{
METODY
}

Badania terenowe na obiektach doświadczalnych obejmowały wiercenia wraz z poborem próbek NW, NNS oraz sondowania dylatometrem sejsmicznym SDMT. W ramach przeprowadzonych prac badawczych wykonano 16 sondowań o głębokości od 9,5 do 16,0 m. Badania wykonywano w węzłach obejmujących od trzech do czterech sondowań dylatometrycznych, zlokalizowanych w bezpośrednim sąsiedztwie otworów badawczych. Wyjątek stanowią badania przeprowadzone na obiekcie Bielany, gdzie wiercenia uzupełniono tylko jednym sondowaniem. Przykład zastosowanego węzła badawczego przedstawiono na rysunku 2.

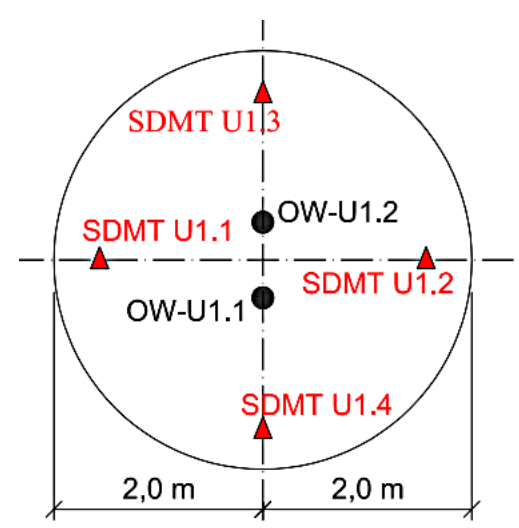

\author{
Objaśnienia \\ Legend \\ otwór badawczy \\ borehole \\ $\Delta$ sondowanie SDMT \\ SDMT test
}

Rys. 2. Przykładowy węzeł badawczy

Fig. 2. An example test node

Badania dylatometryczne przeprowadzono zgodnie z wytycznymi Marchettiego (Marchetti, Monaco, Totani i Calabrese, 2001). Szczegóły związane z wykonywaniem oraz interpretacją badań DMT, SDMT można znaleźć w licznych publikacjach (Marchetti, 1980; Marchetti, Marchetti, Monaco i Totani, 2008; Marchetti, 2014).

Interpretacja wyników badań dylatometrycznych oparta została na trzech podstawowych wskaźnikach: wskaźniku materiałowym $\left(I_{D}\right)$, wskaźniku naprężenia bocznego $\left(K_{D}\right)$, module dylatometrycznym $\left(E_{D}\right)$ - Marchetti (1980). Wymienione wskaźniki uzupełnione o zdefiniowany przez Luteneggera i Kabira (1988) wskaźnik ciśnienia wody w porach $\left(U_{D}\right)$ stanowią podstawę do wydzielania warstw podłoża oraz wyprowadzania parametrów geotechnicznych z wykorzystaniem zależności empirycznych. 
Galas, P. i Lechowicz, Z. (2017). Wyznaczanie wybranych parametrów geotechnicznych prekonsolidowanych gruntów spoistych na podstawie sondowań SDMT. Acta Sci. Pol. Architectura, 16 (3), 69-79. doi: 10.22630/ASPA.2017.16.3.07.

W przeprowadzonych badaniach do generacji fali poprzecznej wykorzystano dwa skonstruowane do tego celu przyrządy: drewnianą oraz stalową belkę (rys. 3). Drewniana belka składała się z 7 drewnianych bali o przekroju 0,12 $\times 0,12 \mathrm{~m}$ i długości 0,4 m każdy. Całkowita długość belki wynosiła $L=0,84 \mathrm{~m}$, a szerokość $B=0,4 \mathrm{~m}$. Poszczególne elementy drewniane zostały połączone stalowymi śrubami, sama zaś belka została obita od czoła stalową blachą o grubości około $10 \mathrm{~mm}$. Drugi przyrząd stanowiła stalowa belka z zamocowaną konstrukcją młota pozwalającą na swobodne uderzenie głowicy młota o czoło belki. Zastosowano młot o masie około $15 \mathrm{~kg}$,

a

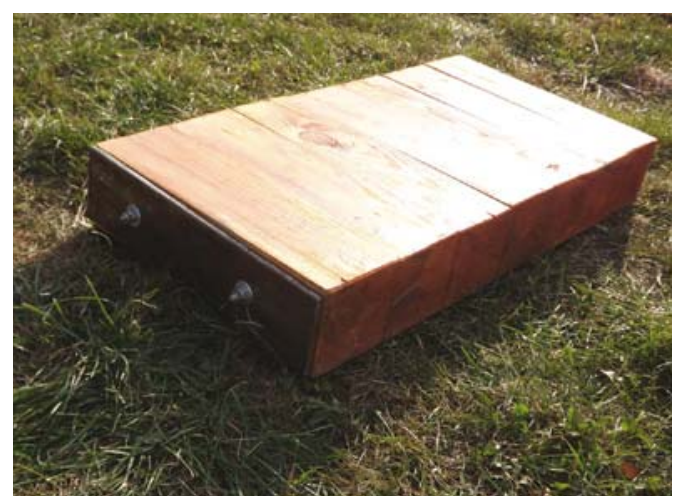

$\mathrm{b}$

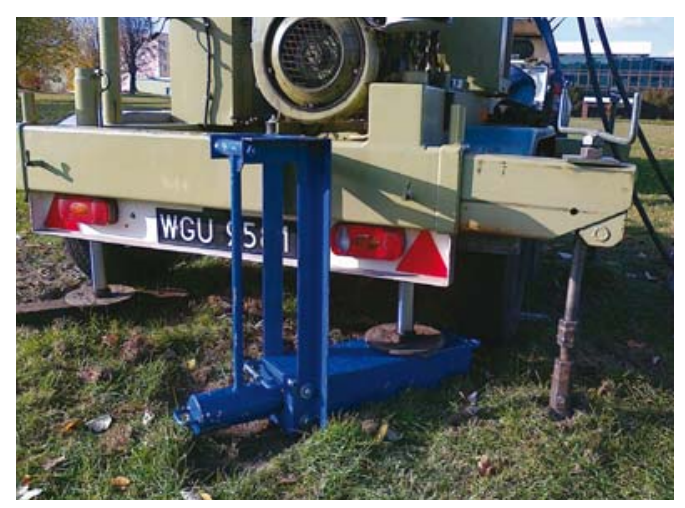

Rys. 3. Przyrządy wykorzystane do wzbudzenia fali poprzecznej: a - drewniana belka, b - stalowa belka (Galas, 2013)

Fig. 3. Shear wave velocity generation devices: $\mathrm{a}$ - wood beam, b - steel beam (Galas, 2013)

Rys. 4. Usytuowanie zanotowanych wskaźników dylatometrycznych na nomogramie klasyfikacyjnym Marchettiego i Crappsa (1981)

Fig. 4. Dilatometers indexes presentation on Marchetti and Crapps (1981) chart belkę o wymiarach $0,2 \times 0,7 \times 0,1 \mathrm{~m}$ oraz grubości blachy około $25 \mathrm{~mm}$, wysokość całego urządzenia - około 0,8 m. Przyrządy wykorzystywane do generacji fali w ośrodku gruntowym umieszczane były pod kołem samochodu lub dociskane do podłoża za pomocą stopy sondy.

\section{WYNIKI}

Jednym z elementów interpretacji badań dylatometrycznych jest ocena rodzaju gruntu badanego podłoża. Dotychczas podstawą takiej interpretacji był nomogram klasyfikacyjny przedstawiony przez Marchettiego i Crappsa (1981). Na rysunku 4 zobrazowano wskaźniki dylatometryczne wyznaczone na podstawie wyników pomiarów wykonanych w prekonsolidowanych gruntach spoistych. Dla przejrzystości rysunku wyniki pomiarów pogrupowano według obiektów doświadczalnych wraz z oznaczeniami zgodnymi z zamieszczoną legendą.

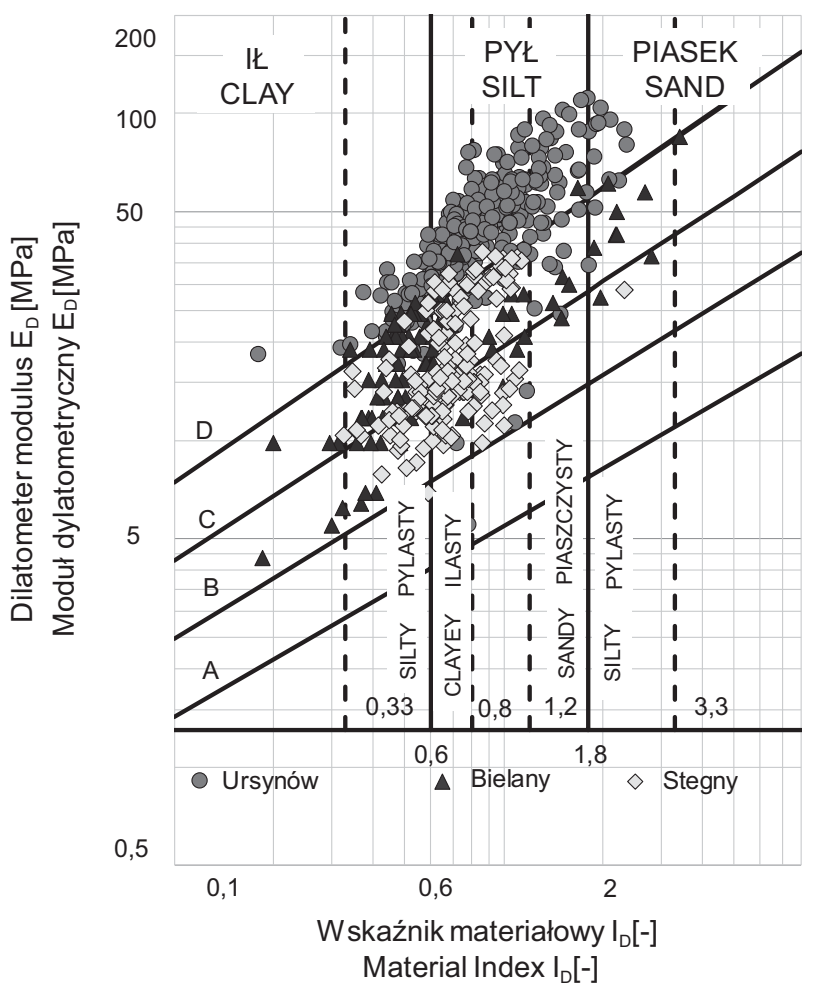

architectura.actapol.net 
Galas, P. i Lechowicz, Z. (2017). Wyznaczanie wybranych parametrów geotechnicznych prekonsolidowanych gruntów spoistych na podstawie sondowań SDMT. Acta Sci. Pol. Architectura, 16 (3), 69-79. doi: 10.22630/ASPA.2017.16.3.07.

Wykonane na obiektach doświadczalnych pomiary wskazują na zgrupowanie badanych gruntów wokół linii D (obiekt Ursynów) oraz w obszarze między liniami C i B (obiekty Bielany, Stegny). Pomiary wykonane w gruntach spoistych na terenie Ursynowa, według nomogramu Marchettiego i Crappsa, klasyfikują badane grunty jako podłoże w stanie półzwartym i zwartym. W przypadku obiektów Stegny i Bielany usytuowanie pomiarów na nomogramie klasyfikacyjnym wskazuje na zaleganie gruntów w stanie półzwartym i twardoplastycznym. Wyniki badań laboratoryjnych, zamieszone w tabeli 1, potwierdzają interpretację badań dylatometrycznych. Stan gruntu określony na podstawie pomiarów dylatometrycznych wykazuje zgodność z wynikami badań laboratoryjnych.

Tabela 1. Zestawienie wyników badań właściwości fizycznych

Table 1. Index properties of tested soils

\begin{tabular}{|c|c|c|c|c|c|c|}
\hline $\begin{array}{l}\text { Obiekt } \\
\text { doświadczalny } \\
\text { Test site }\end{array}$ & $\begin{array}{l}\text { Parametr } \\
\text { Parameter }\end{array}$ & $\begin{array}{c}\text { Liczba } \\
\text { pomiarów } \\
\text { Number of } \\
\text { measurements }\end{array}$ & $\begin{array}{c}\text { Średnia } \\
\text { Average value }\end{array}$ & $\begin{array}{c}\text { Mediana } \\
\text { Median }\end{array}$ & $\begin{array}{c}\text { Minimum } \\
\text { Minimum value }\end{array}$ & $\begin{array}{c}\text { Maksimum } \\
\text { Maximum value }\end{array}$ \\
\hline \multirow{5}{*}{ Ursynów } & $w_{n}[\%]$ & \multirow{5}{*}{21} & 10,5 & 10,4 & 8,6 & 12,8 \\
\hline & $w_{p}[\%]$ & & 12,2 & 12 & 11,0 & 13,5 \\
\hline & $w_{L}[\%]$ & & 23,9 & 24,3 & 21,3 & 26,6 \\
\hline & $I_{p}[\%]$ & & 11,7 & 12,0 & 9,3 & 14,1 \\
\hline & $I_{L}[-]$ & & $-0,14$ & $-0,13$ & $-0,27$ & 0,01 \\
\hline \multirow{5}{*}{ Bielany } & $w_{n}[\%]$ & \multirow{5}{*}{12} & 16,4 & 13,8 & 10,4 & 29,7 \\
\hline & $w_{p}[\%]$ & & 14,4 & 13,5 & 11,0 & 18,8 \\
\hline & $w_{L}[\%]$ & & 29,7 & 28,0 & 14,0 & 45,1 \\
\hline & $I_{p}[\%]$ & & 15,2 & 16,3 & 2,7 & 26,7 \\
\hline & $I_{L}[-]$ & & 0,12 & 0,12 & $-0,22$ & 0,44 \\
\hline \multirow{5}{*}{ Stegny } & $w_{n}[\%]$ & \multirow{5}{*}{6} & 24,6 & 23,9 & 19,8 & 30,1 \\
\hline & $w_{p}[\%]$ & & 25,1 & 25,2 & 20,4 & 31,2 \\
\hline & $w_{L}[\%]$ & & 82,9 & 87,1 & 67,6 & 89,4 \\
\hline & $I_{p}[\%]$ & & 57,9 & 59,7 & 42,1 & 67,1 \\
\hline & $I_{L}[-]$ & & $-0,01$ & $-0,0$ & $-0,13$ & 0,15 \\
\hline
\end{tabular}

Interpretacja rodzaju gruntu na podstawie pomiarów dylatometrycznych oparta została na wskaźniku materiałowym $\left(I_{D}\right)$ - Marchetti (1980). Według nomogramu Marchettiego i Crappsa (1981) grunty z obiektu Ursynów znajdują się w obszarze odpowiadającym pyłom, pyłom ilastym, pyłom piaszczystym, a nawet piaskom pylastym. Wyniki analiz granulometrycznych (rys. 5) wskazują na występowanie iłów piaszczystych (saCl) oraz iłów piaszczysto-pylastych ( $\mathrm{sasiCl}$ ). Grunty z obiektów Bielany i Stegny, według nomogramu Marchettiego i Crappsa, można zaklasyfikować głównie jako pyły, pyły ilaste oraz iły pylaste. Badania laboratoryjne potwierdziły stan gruntów, natomiast analiza granulometryczna wskazuje na występowanie iłów piaszczystych $(\mathrm{saCl})$, iłów pylasto-piaszczystych ( $\mathrm{sasiCl}$ ) w przypadku obiektu Stegny oraz pyłów piaszczystych (saSi), iłów piaszczystych (saCl) oraz iłów pylasto-piaszczystych (sasiCl) dla obiektu Bielany. 
Galas, P. i Lechowicz, Z. (2017). Wyznaczanie wybranych parametrów geotechnicznych prekonsolidowanych gruntów spoistych na podstawie sondowań SDMT. Acta Sci. Pol. Architectura, 16 (3), 69-79. doi: 10.22630/ASPA.2017.16.3.07.

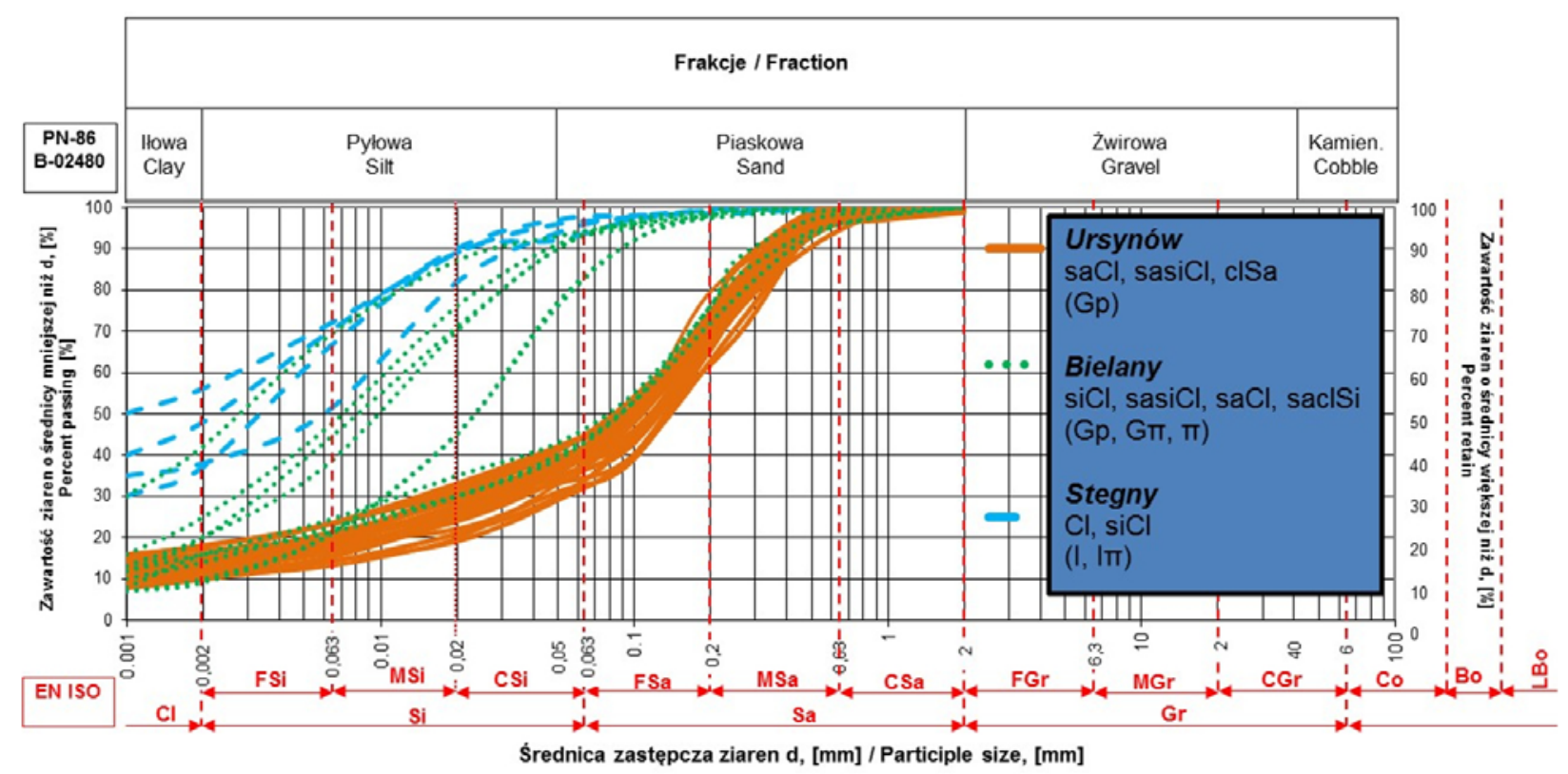

Rys. 5. Zestawienie krzywych uziarnienia badanych gruntów

Fig. 5. Grain-size distributions of tested soils

Część pomiarów na nomogramie Marchettiego i Crappsa znalazła się w rejonie właściwym dla gruntów niespoistych, przy wartości wskaźnika $I_{D}$ przekraczającej 1,80, która stanowi wartość graniczną oddzielającą grunty spoiste od niespoistych. Przyczyny takiego stanu można upatrywać w zawartości frakcji piaskowej oraz historii naprężenia badanych gruntów. Grunty zlodowacenia Warty oraz Odry wykazują bardzo dużą zawartość frakcji piaskowej, sięgającą nawet $65 \%$. Duże wartości wskaźnika materiałowego $\left(I_{D}\right)$ - rysunek $6 \mathrm{c}$ i wynikającą $\mathrm{z}$ tego błędną interpretację rodzaju gruntu należy również wiązać $\mathrm{z}$ historią naprężenia badanych gruntów. Największe wartości wskaźnika naprężenia bocznego $\left(K_{D}\right)$ wyznaczono na podstawie przeprowadzonych pomiarów na obiekcie Ursynów (rys. 6e), czyli obiekcie, z którego próbki wskazały jednocześnie na największą zawartość frakcji piaskowej. Znacznie mniejsze wartości zanotowano w mało i średnio spoistych gruntach obiektu Bielany (wartość średnia $K_{D}=6,1$ ) oraz bardzo spoistych gruntach obiektu Stegny (wartość średnia $K_{D}=5,9$ ). Nawiązując do wyników przedstawionych przez Lacasse i Lunne (1988), należy podkreślić, iż w gruntach mineralnych wzrost wartości wskaźnika prekonsolidacji związany jest nie tylko ze wzrostem modułu dylatometrycznego $\left(E_{D}\right)$, ale również wskaźnika materiałowego $\left(I_{D}\right)$. Thumaczy to propozycję Larssona (1989), który dla gruntów prekonsolidowanych zalecił wprowadzenie korekty wartości wskaźnika materiałowego $\left(I_{D}\right)$, uwzględniającej wpływ historii naprężenia na jego wartość.

Wartość wskaźnika naprężenia bocznego $\left(K_{D}\right)$ powiązana jest z ciśnieniem $p_{0}$, wskaźnik $I_{D}$ zaś z różnicą ciśnień $p_{1}-p_{0}$. Grunty, które wykazały największą wartość wskaźnika $K_{D}$, jednocześnie osiągnęły największą wartość ciśnień $p_{0}$ i $p_{1}$ (rys. 7) oraz stosunku ciśnień $p_{1} / p_{0}$ (gliny zwałowe zlodowacenia Warty i Odry - rys. 6a, b). Konsekwencją wzrostu różnicy ciśnień $p_{1}-p_{0}$ jest wzrost wartości wskaźnika materiałowego $\left(I_{D}\right)$ i przesunięcie lokalizacji pomiarów na nomogramie Marchettiego i Crappsa w kierunku gruntów niespoistych. W świetle przeprowadzonych badań w przypadku silnie prekonsolidowanie gruntów spoistych określenie rodzaju gruntu wyłącznie na podstawie pomiarów dylatometrycznych nie daje dobrych rezultatów. Wykorzystanie nomogramu Marchettiego i Crappsa wiąże się z koniecznością wykonania uzupełniających badań laboratoryjnych. 


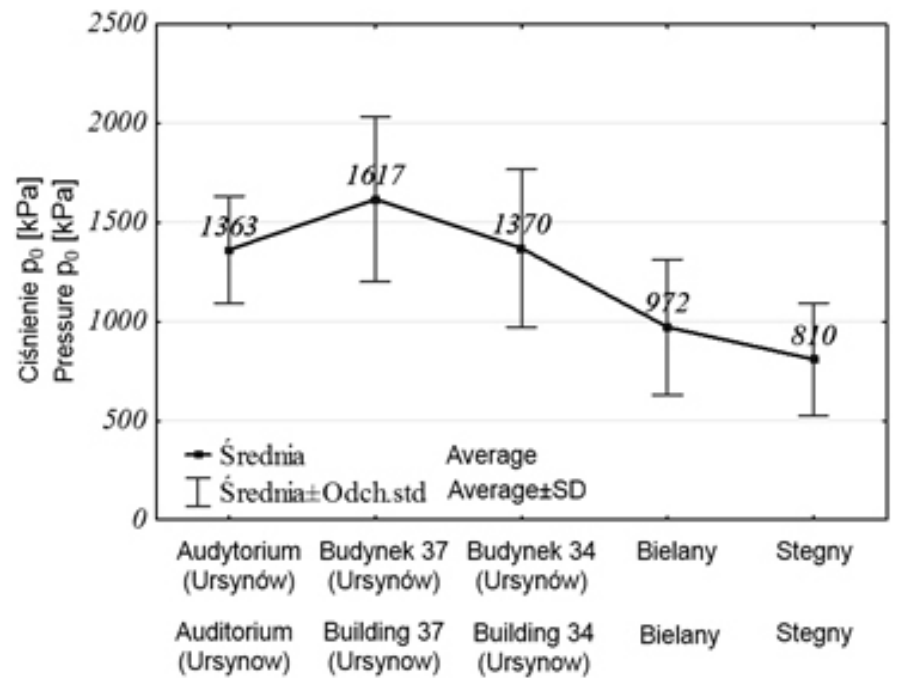

C

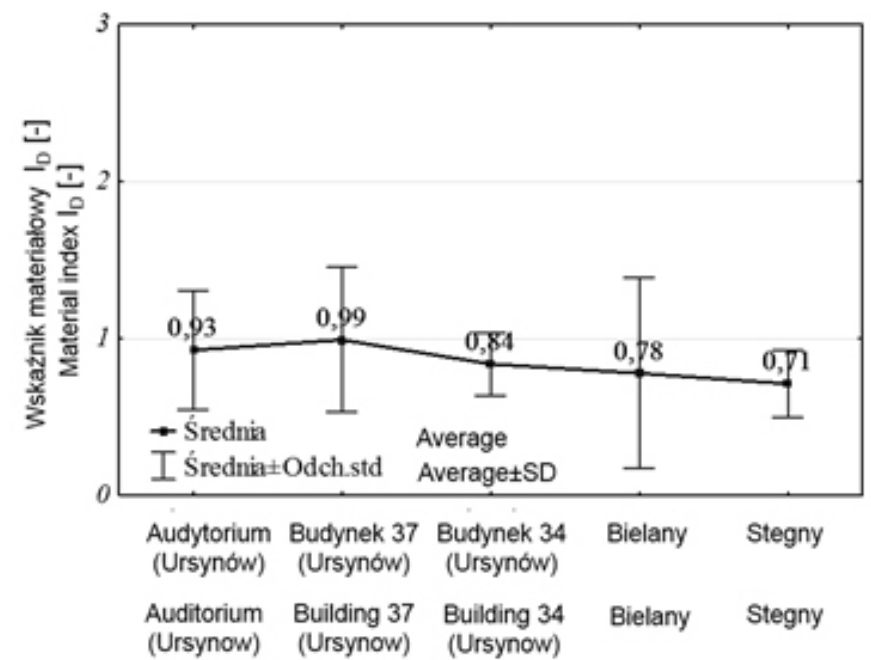

e

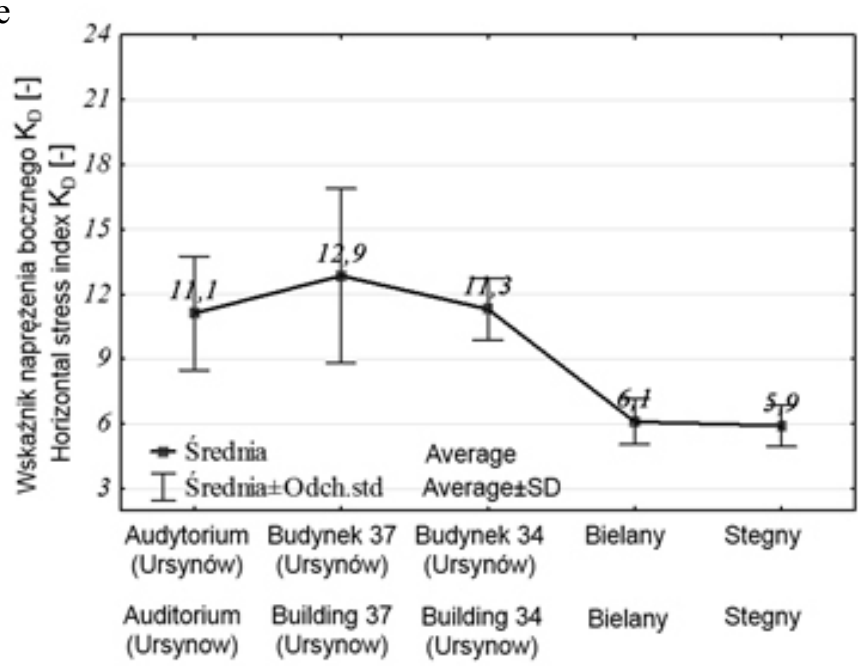

b

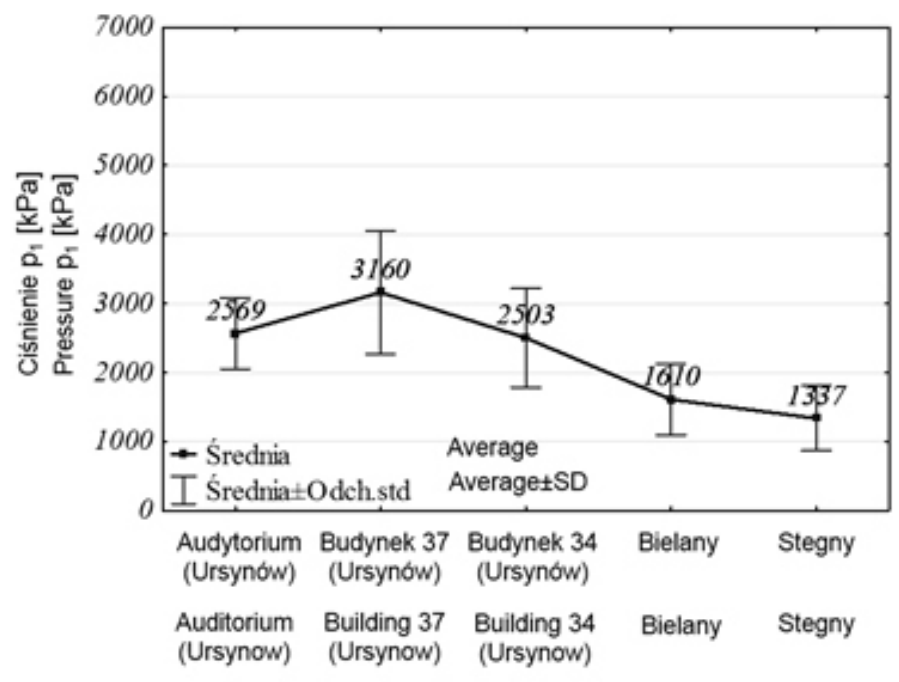

d

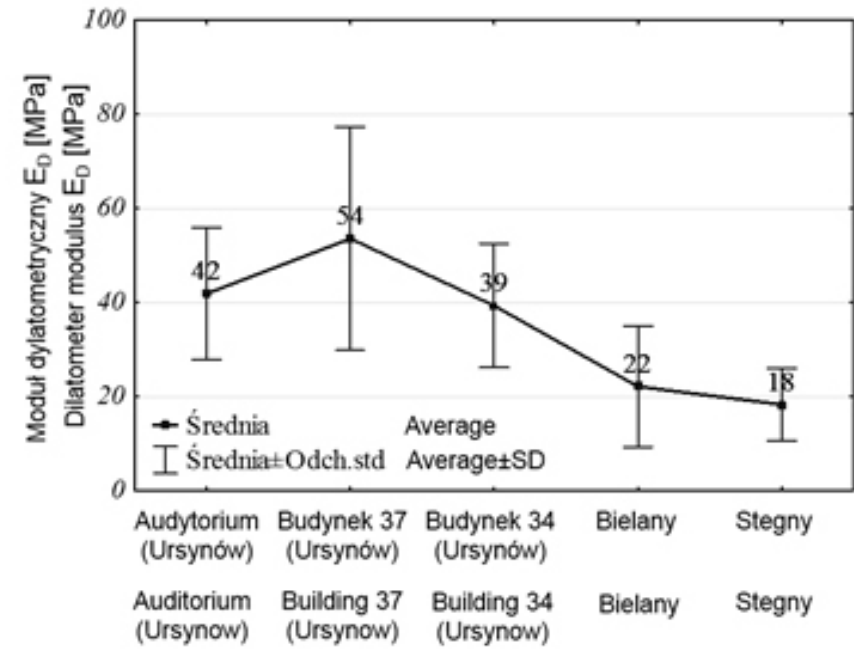

f

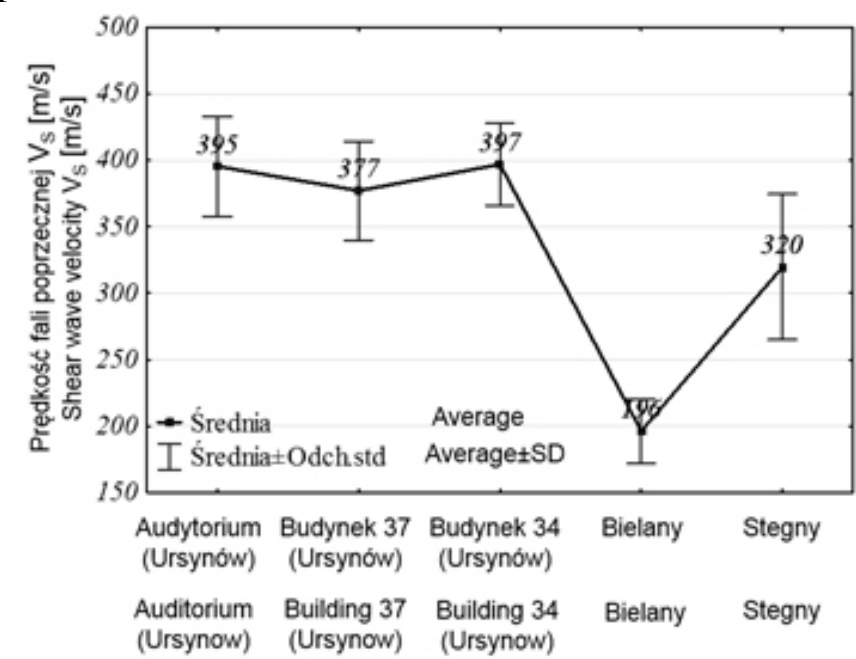

Rys. 6. Wartości średnie uzyskane na podstawie badań dylatometrycznych: a - ciśnienie $p_{0}, \mathrm{~b}-$ ciśnienie $p_{1}, \mathrm{c}-$ wskaźnik materiałowy $\left(I_{D}\right), \mathrm{d}$ - moduł dylatometryczny $\left(E_{D}\right), \mathrm{e}$ - wskaźnik naprężenia bocznego $\left(K_{D}\right), f$ - prędkość fali poprzecznej $\left(V_{S}\right)$

Fig. 6. Average values of parameters derived from seismic flat dilatometer tests: $\mathrm{a}-p_{0}$ pressures, $\mathrm{b}-p_{1}$ pressures, $\mathrm{c}-$ material index $\left(I_{D}\right)$, $\mathrm{d}$ - dilatometer modulus $\left(E_{D}\right)$, e - horizontal stress index $\left(K_{D}\right), f$ - shear wave velocity $\left(V_{S}\right)$ 

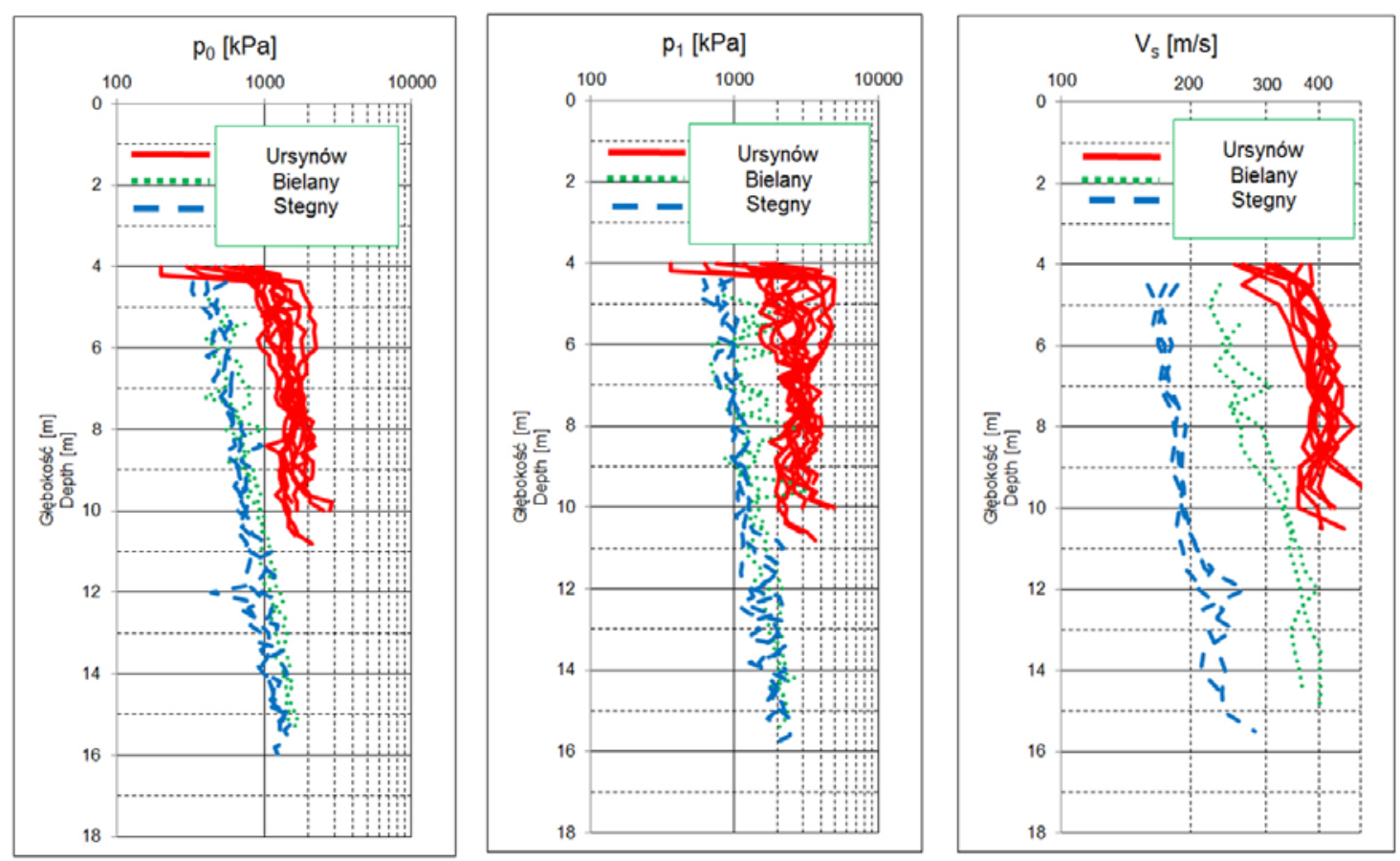

Rys. 7. Profile ciśnień $p_{0}$ i $p_{1}$ oraz prędkości fali poprzecznej $\left(V_{s}\right)$ pomierzone na obiektach doświadczalnych

Fig. 7. Profiles of $p_{0}, p_{1}, V_{s}$ from the analyzed test sites

\section{ANALIZA WYNIKÓW}

W ramach przeprowadzonych prac wykonano analizę zależności stosunku $G_{0} / E_{D}$ oraz $G_{0} / M_{D M T}$ z pomiarami ciśnień $p_{0}, p_{1}$ oraz wskaźnikami dylatometrycznymi wraz z doborem odpowiedniej funkcji opisującej zmianę początkowego modułu ścinania $\left(G_{0}\right)$. Dla badanych gruntów najlepszą korelację parametru $\left(G_{0}\right)$ uzyskano ze wskaźnikiem materiałowym $\left(I_{D}\right)$. Zwiększenie dokładności opracowanych zależności uzyskano poprzez rozdzielenie gruntów mało spoistych $\left(I_{p}<20 \%\right)$ oraz bardzo spoistych $\left(I_{p}=40 \div 60 \%\right)$. Niezależnie od spoistości gruntu najlepszą korelację uzyskano dla funkcji potęgowej. Dzieląc zebrane wyniki badań ze względu na spoistość gruntów, otrzymano zbiór obejmujący 297 pomiarów dla gruntów o wartości $I_{p}<20 \%$ oraz 115 pomiarów dla gruntów o wartości $I_{p}=40 \div 60 \%$ (rys. 8).

Wydzielone grupy pozwoliły na opracowanie zależności umożliwiających wyznaczanie początkowego modułu ścinania na podstawie badań standardowym dylatometrem Marchettiego DMT. Początkowy moduł ścinania $\left(G_{0}\right)$ proponuje się wyznaczać na podstawie następujących zależności (Galas, 2013):

- grunty mało i średnio spoiste $\left(I_{p}<20 \%\right)$

$$
G_{0} / E_{D}=6,28 I_{D}^{-1,02}
$$

- grunty bardzo spoiste $\left(I_{p}=40 \div 60 \%\right)$

$$
G_{0} / E_{D}=3,25 I_{D}^{-0,80} \mathrm{~m}
$$

Współczynnik determinacji dla gruntów mało i średnio spoistych wyniósł $\mathrm{R}^{2}=0,80$, a dla gruntów bardzo spoistych $\mathrm{R}^{2}=0,70$. Należy podkreślić, iż zmiana wartości $G_{0} / E_{D}$ jest silnie związana nie tylko z rodzajem gruntu, ale również historią naprężenia (rys. 9). 
Galas, P. i Lechowicz, Z. (2017). Wyznaczanie wybranych parametrów geotechnicznych prekonsolidowanych gruntów spoistych na podstawie sondowań SDMT. Acta Sci. Pol. Architectura, 16 (3), 69-79. doi: 10.22630/ASPA.2017.16.3.07.

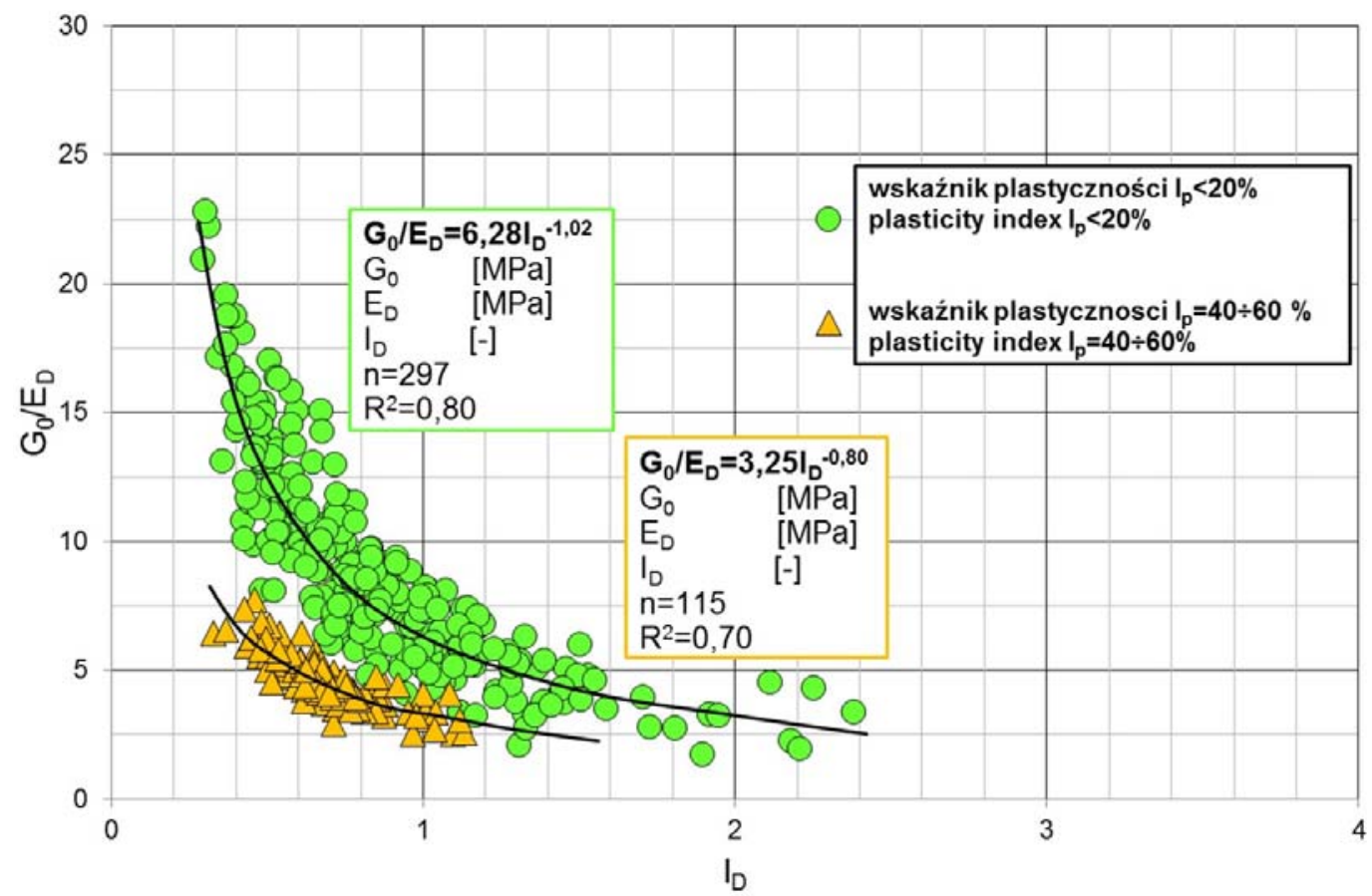

Rys. 8. Zmiana stosunku $G_{0} / E_{D}$ w zależności od wskaźnika materiałowego $\left(I_{D}\right)$

Fig. 8. Change of $G_{0} / E_{D}$ ratio with material index $\left(I_{D}\right)$

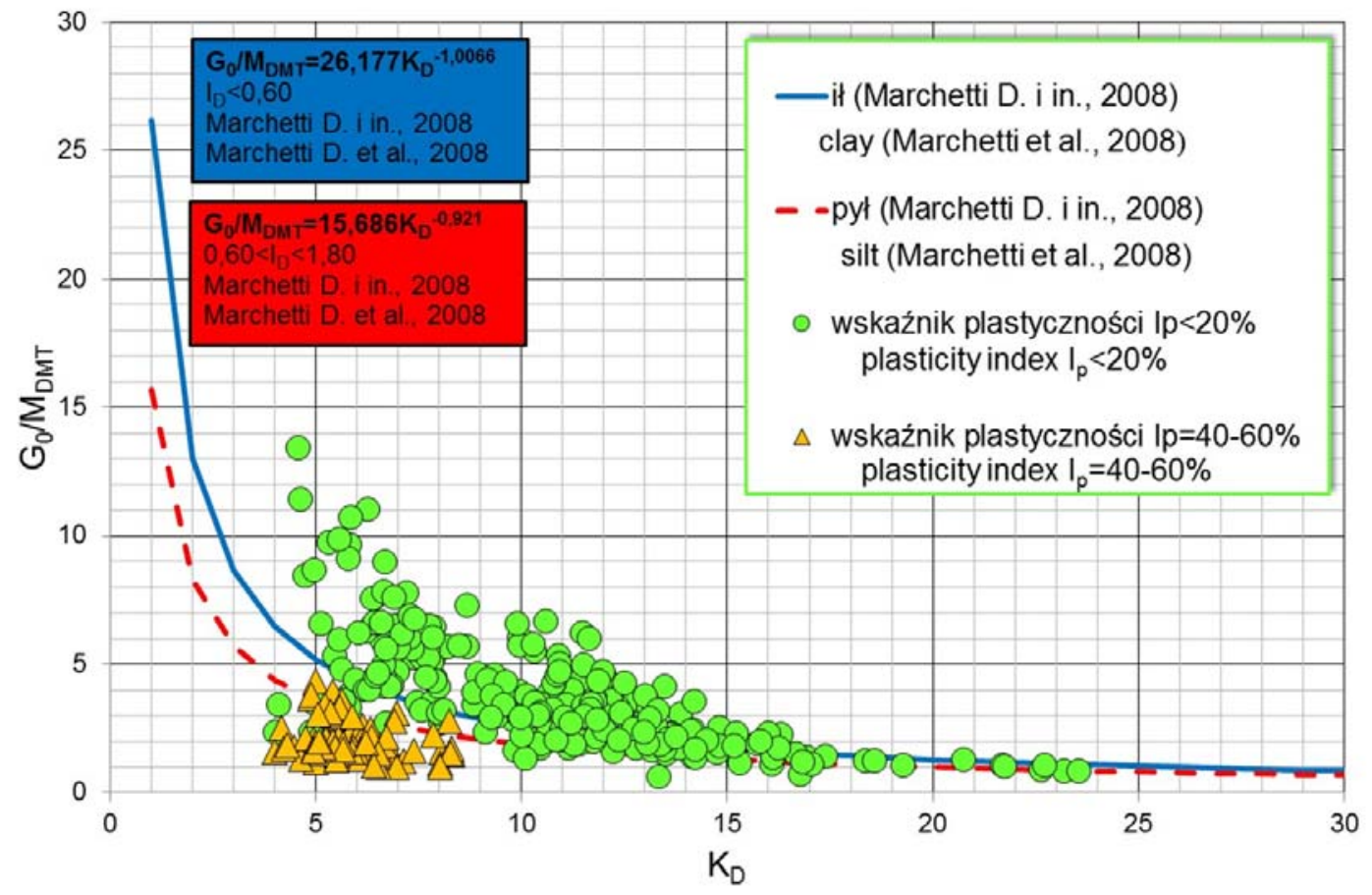

Rys. 9. Zmiana stosunku $G_{0} / M_{D M T}$ w zależności od wskaźnika naprężenia bocznego $\left(K_{D}\right)$

Fig. 9. Change of $G_{0} / M_{D M T}$ ratio with horizontal stress index $\left(K_{D}\right)$ 
Zebrane wyniki pomiarów pogrupowane ze względu na wskaźnik plastyczności uzupełniono o równania zaproponowane przez Marchettiego (Marchetti i in., 2008). Otrzymane wyniki wpisują się w trend przedstawiony w literaturze (Marchetti i in., 2008; Monacco, Marchetti, Totani i Marchetti, 2009; Marchetti, 2014). W gruntach bardzo spoistych $\left(I_{p}>40 \%\right)$ stosunek $G_{0} / M_{D M T}$ przyjmuje wartości z zakresu od 1 do 4 . Znacznie większy zakres zmienności $G_{0} / M_{D M T}$ wykazały grunty mało spoiste $\left(I_{p}<20 \%\right)$, dla których zanotowano zakres od 1 do do 14 . W obu rozpatrywanych grupach zwiększeniu wartości wskaźnika naprężenia bocznego odpowiada zmniejszenie wartości stosunku $G_{0} / M_{D M T}$

\section{WNIOSKI}

Przeprowadzone badania prekonsolidowanych gruntów spoistych pozwalają na sformułowanie następujących wniosków:

1. Porównanie stanu gruntów spoistych na podstawie wyników badań laboratoryjnych oraz nomogramu Marchettiego i Crappsa należy ocenić pozytywnie. Otrzymane wyniki uzyskane na każdym z obiektów doświadczalnych wykazały dobrą zgodność w ocenie stanu gruntów.

2. W przypadku silnie prekonsolidowanych gruntów spoistych określenie rodzaju gruntu wyłącznie na podstawie pomiarów dylatometrycznych nie daje dobrych rezultatów. Wykorzystanie nomogramu Marchettiego i Crappsa wiąże się z koniecznością wykonania uzupełniających badań laboratoryjnych.

3. Przeprowadzone badania umożliwiły określenie zależności pomiędzy stosunkiem $G_{0} / E_{D}$ a wskaźnikiem materiałowym $\left(I_{D}\right)$. Wraz ze wzrostem wartości wskaźnika materiałowego następuje zmniejszenie wartości $G_{0} / E_{D}$ Z Zwiększenie dokładności opracowanych zależności uzyskano poprzez rozdzielenie badanych gruntów na dwie grupy: mało spoiste $\left(I_{p}<20 \%\right)$ oraz bardzo spoiste $\left(I_{p}=40 \div 60 \%\right)$.

4. Zwiększeniu wartości wskaźnika naprężenia bocznego $\left(K_{D}\right)$ odpowiada zmniejszenie wartości stosunku $G_{0} / M_{D M T}$ Zmniejszenie $G_{0} / M_{D M T}$ powiązane jest z większym wpływem wskaźnika prekonsolidacji (OCR) w zakresie średnich odkształceń na sztywność gruntu w stosunku do zakresu małych odkształceń. Niezbędne są dalsze badania rozszerzające zakres badanych gruntów w odniesieniu do wskaźnika naprężenia $K_{D}<5$ oraz gruntów o odmiennej spoistości.

\section{PIŚMIENNICTWO}

Galas, P. (2013). Wyznaczanie wytrzymałości na ścinanie gruntów spoistych na podstawie badań SDMT. (praca doktorska). Warszawa: SGGW.

Lacasse, S. i Lunne, T. (1988). Calibration of dilatometer corrections. Proceedings of the 1st International Symposium on Penetration testing, 1, Orlando, 519-522.

Larsson, R. (1989). DilatometerFörsök för bedömning au jordlagerföljd och egenskaper i jord. Swedish Geotechnical Institute, Linköping, Information 10. Swedish.

Lutenegger, A. J. i Kabir, M. G. (1988). Dilatometer C-reading to help determine stratigraphy. Proceedings of the 1 st International Symposium on Penetration testing, 1, Orlando, 549-553.

Marchetti, D., Monaco, P., Totani, G. i Calabrese, M. (2001). The Flat dilatometer test (DMT) in soil investigation. In Proceedings of the International Conference on in situ measurement of soil properties. Bali.

Marchetti, D., Marchetti, S., Monaco, P. i Totani, G. (2008). Experience with seismic dilatometer (SDMT) in various soil types. Geotechnical and Geophysical Site Characterization, Taipei, 1339-1345.

Marchetti, S. (1980). In situ tests by flat dilatometer. Journal of the Geotechnical Engineering Division, ASCE, 106 (3), 299-321.

Marchetti S., (2014). The seismic Dilatometer for In Situ Soil Investigations. Proceedings Indian Geotechnical Conference IGC - Kakinada, India.

Marchetti, S. i Crapps, D. (1981). Flat dilatometer manual. Schmertmann and Crapps Inc. Gainesville, Florida, USA. 
Młynarek, Z., Gogolik, S. i Marchetti, D. (2006). Suitability of the SDMT method to assess geotechnical parameters of postflotation sediments. 2nd International Conference on the Flat Dilatometer. Washington, 148-152.

Monaco, P., Marchetti, S., Totani, G. i Marchetti, D., (2009). Interrelationship Between Small Strain Modulus G and Operative Modulus. Proc. International Conference on Performance Based Design in Earthquake Geotech. Eng. IS - Tokyo, Japan.

\title{
EVALUATION OF SELECTED GEOTECHNICAL PARAMETERS OF PRECONSOLIDATED COHESIVE SOILS BASED ON SDMT
}

\begin{abstract}
The paper presents seismic flat dilatometer tests (SDMT) results carried out at selected test sites located in Warsaw. The primary focus has been given to analysis of preconsolidated cohesive soils. Both, in situ, as well as, laboratory test results are presented and discussed. The paper briefly presents soil conditions at each test site, and describes the test carried out. Based on the comparison of the results of laboratory tests with the results of the SDMT, an assessment of the use of the Marchetti and Crapps nomogram was made to determine the type and state of the tested cohesive soils. Analysis of the results of the SDMT allowed to develop for the investigated cohesive soils the empirical relationship between the $G_{0} / E_{D}$ ratio and the material index $I_{D}$.
\end{abstract}

Key words: seismic flat dilatometer, preconsolidated cohesive soils, soil stiffness, initial shear modulus 